\title{
A new shark and ray fauna from the Middle Miocene of Mazan, Vaucluse (southern France) and its importance in interpreting the paleoenvironment of marine deposits in the southern Rhodanian Basin
}

\author{
Nicolas Vialle $\cdot$ Sylvain Adnet $\cdot$ Henri Cappetta
}

Received: 10 March 2011/ Accepted: 29 August 2011/Published online: 16 September 2011

(C) Akademie der Naturwissenschaften Schweiz (SCNAT) 2011

\begin{abstract}
Recent paleontological excavations of the Middle Miocene sandstones (top of the "Schlier" facies) near Mazan, Vaucluse (southern France) uncovered a rich selachian teeth assemblage including 34 shark and ray species. This great diversity of selachian taxa provides new information about the palaeoenvironmental settings of some Middle Miocene deposits in the southern Rhodanian basin. For instance, the co-occurrence of some deepwater Squaliformes and Rajidae with numerous Carcharhiniformes and Myliobatiformes, usually inhabiting the continental shelf, suggests a deepwater deposit inshore, as adjacent to a submarine canyon area.
\end{abstract}

Keywords Selachians $\cdot$ Middle Miocene $\cdot$ Southern France $\cdot$ Southern Rhodanian basin $\cdot$ Paleoenvironment

\section{Introduction}

The earliest studies on the Miocene fossil selachians from Vaucluse were by Fischer (1878); Leriche (1906) and Joleaud $(1907,1912)$ who published a detailed review of the selachian remains from the southern Rhodanian basin. These faunas were partially updated from new material (Cappetta et al. 1967; Ledoux 1972) or from comparative analysis with nearby contemporaneous localities (Cappetta 1970, 1973). More recently, Brisswalter (2009) published a note on new selachian teeth assemblages collected during

N. Vialle $\cdot$ S. Adnet $(\bowtie) \cdot$ H. Cappetta

Laboratoire de Paléontologie, UMR 5554, Institut des Sciences

de l'Evolution, Université de Montpellier II, Sciences et

Techniques du Languedoc, Cc 064, Place Eugène Bataillon,

34095 Montpellier Cedex 5, France

e-mail: sylvain.adnet@univ-montp2.fr the last decades from several localities in the Natural Park of Lubéron (South of Vaucluse). Selachian associations recovered in the Middle Miocene of Vaucluse are quite particular because they indicate either neritic or deepwater deposits. Such difference in faunal composition between sites can be interpreted as a difference in age, a geographical heterogeneity of environmental deposits or a mixture of both. A new fossil locality, found in 2007 near Mazan, was collected by one of the authors (H. Cappetta) with the kind help of Eric Collier. A preliminary analysis indicates that the new rich selachian fauna comprises both types of the previous associations. The aim of this work is to improve our knowledge about the selachian diversity in the southern Rhodanian basin during the Middle Miocene, by listing in detail the selachians from Mazan and comparing them with material collected in Vaucluse and in neighbouring areas of Hérault.

\section{Geological settings}

The fossil locality of "Mazan" (Fig. 1) is located at eight kilometres east of Carpentras (GPS coordinates: $\left.\mathrm{N} 044^{\circ} 03^{\prime} 02.8^{\prime \prime} \mathrm{E} 005^{\circ} 08^{\prime} 15.8^{\prime \prime}\right)$ and is mapped as "Helvetian" (BRGM 1975) formally equivalent to the LanghianSerravallian period. This age was formerly reported as Vindobonian by Demarcq (1970), a local stage which corresponds precisely to the lower part of the so-called "Helvetian", and thus, to the Langhian only. The sediment consists of grey sandstone, composed of sorted sand, that outcrops as a monotonous layer around Carpentras (Joleaud 1907, 1912). The thickness of this layer varies between 350 and $500 \mathrm{~m}$ (Demarcq 1970) according to its erosion and location. This unnamed formation probably corresponds to the upper part of the blue "Schlier" marls Formation that 


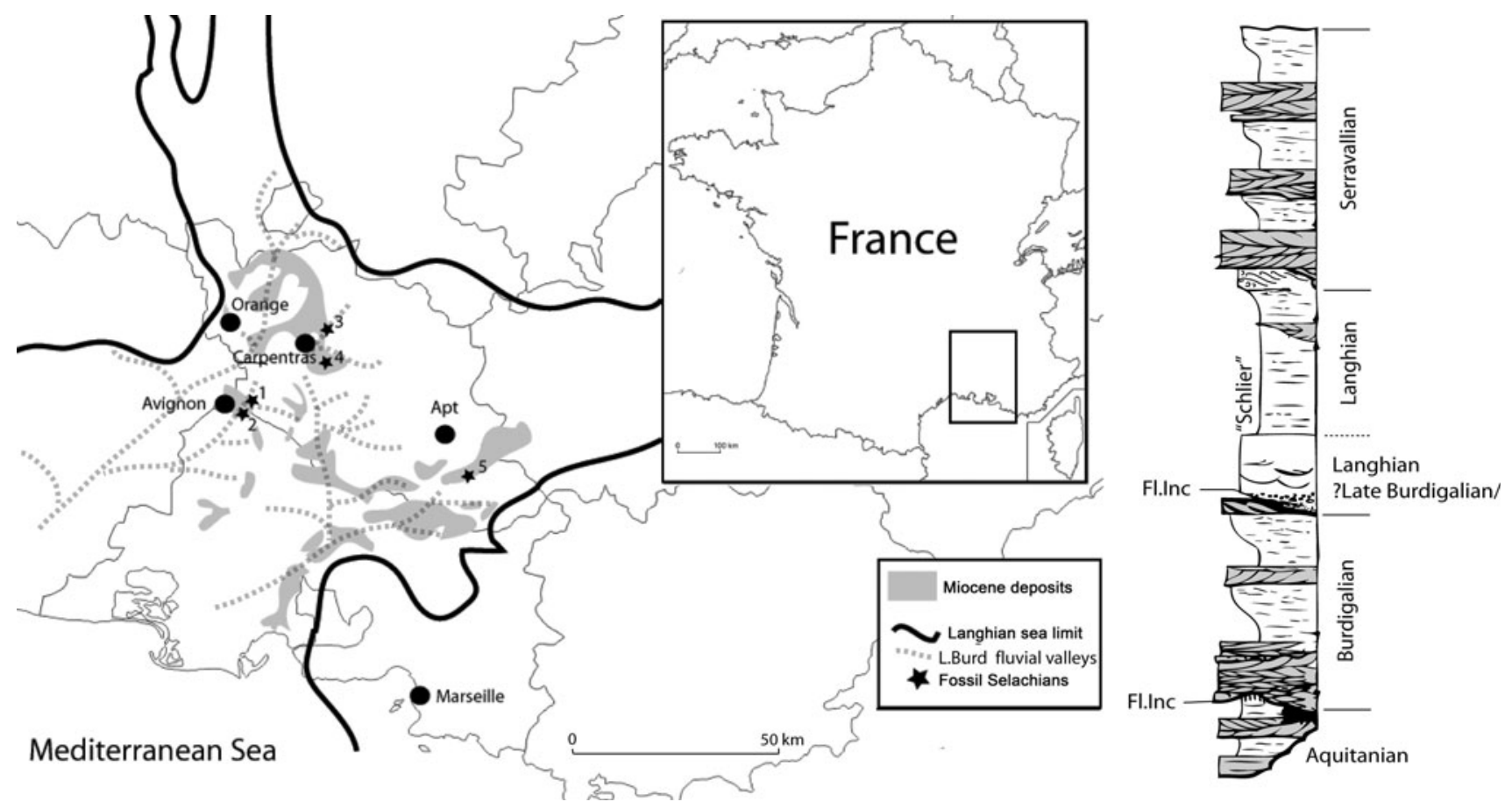

Fig. 1 Left. Map of the major Miocene deposits of Vaucluse with selachian teeth: 1, "Bonpas"; 2, "Caumont"; 3, "Mazan"; 4, "SaintDidier"; 5, "Cabrières d'Aigues" (redraw after Demarcq, 1970 modified and Besson et al. 2005 for the Latest Burdigalian network of fluvial valleys: L. Burd fluvial valleys). Right. Early-Middle Miocene

occurs in the entire "Miocene Molasse basin in the RhoneProvence" area (Gignoux 1960; Demarcq 1970). Besson et al. (2005) recently confirmed the Langhian age of these peculiar sandstones and sandy marls, which are sandwiched between two major molasse deposits (see Fig. 1).

In these sandstones layers, Joleaud $(1907,1912)$ and later Cappetta et al. (1967) reported a relatively deepwater shark fauna near "Bonpas", at the SW of our study area. Closer, the fossil locality of "Saint-Didier" (Ledoux 1972) exhibits similar sandstone layers and a similar selachian fauna with numerous deepwater taxa. These deepwater faunas are clearly different from those previously recovered elsewhere in the Middle Miocene of southern Rhodanian basin by senior authors (Fischer 1878; Leriche 1906; (Joleaud 1907, 1912) but they are consistent with recent studies (Besson 2005; Besson et al. 2005) on the dynamics of the "Rhodano-Provençal" basin that observed that the Middle Miocene has been marked by two maximal transgressions, one dated as Langhian and the second as Serravallian.

\section{Systematic palaeontology}

A $60 \mathrm{~kg}$ sediment sample was sieved through a series of screens, the finest of which was $0.3 \mathrm{~mm}$. Residues were
Lithostratigraphic framework of the Rhone-Provence Molassic series, simplified from Besson et al., 2005. Black: continental surfaces, grey: Bioclastic limestone-dominated deposits ("molasse" s.s.), white: Sand and marl-dominated deposits. Fl.In: Major Fluvial incisions

dried, then treated with a $10 \%$ solution of acetic acid over a period of 1 or 2 days according to the size and quantity of the residues. After rinsing in clean water and drying, the final residues were sorted under a binocular microscope. The fossil material consisted exclusively of isolated selachian teeth, many teeth and vertebral centra of Actinopterigians and fragmentary bones of marine vertebrates. The selachian teeth, particularly those of sharks, were often in poor state of preservation with only the crowns remaining. The smaller teeth, ranging in size between 2 and $4 \mathrm{~mm}$ were the most complete. The poor preservation of the larger fractions is probably due to taphonomic bias. This assumption is supported by observation that many small teeth are rounded, suggesting that the material may have been carried on the sea floor before final deposition. It is thus possible that part of material collected at "Mazan" was not strictly autochtonous and has been transported from nearby. All the figured material is housed in the University of Montpellier (Collection number with abbreviation MAZ). The systematics and dental terminology of taxa follow Cappetta (1987, 2006). The studied fossil material represents 25 species of sharks belonging to 22 genera and 9 species of rays shared in 8 genera. Only three genera are recognized as exclusively fossils: Paraheptranchias, "Oligodalatias" and Carcharoides. 
Order Hexanchiformes Buen, 1926

Family Heptranchidae Barnard, 1925

Genus Paraheptranchias Pfeil, 1981

Paraheptranchias repens (Probst, 1879)

Notidanus repens (Probst, 1879)

Notidanus avenionensis (Joleaud, 1912)

Material: 5 incomplete teeth.

This unusual species is represented by incomplete fragments, primarily of the crown, probably those of lower teeth. The root is missing. The main cusp is highly developed with a sigmoid shape. The mesial cutting edge is limited to the upper part of the cusp. The cusp is flanked by small denticles, which generally separate the acrone from the accessory cusplets.

Remarks. This peculiar species was described by Probst (1879) in the early Miocene of Germany and well illustrated by Barthelt et al. (1991). Joleaud (1912) also reported a unique specimen of $P$. repens, formerly as Notidanus avenionensis, from the Middle Miocene deposits in the region of Avignon, southern France (Cappetta 1970, 1987).

Family Hexanchidae Gray, 1851

Genus Hexanchus Rafinesque, 1810

Hexanchus sp.

Material: 2 teeth.

The two teeth are both crown fragments, probably from lower teeth. The crown is easily separated from the previous taxon by the large number of accessory cones, which decrease regularly distally. On one tooth, one can observe a small serration on the lower half of the mesial cutting edge of acrocone.

Remarks. The living species Hexanchus griseus Bonnaterre, 1788 is known from southern France from the Pliocene in Le-Puget-sur-Argens (Var) (Cappetta and Nolf, 1991). It was recently reported in the Langhian-Serravallian of Cabrières d'Aigues (Vaucluse) (Brisswalter 2009). The poor state of preservation is insufficient to confirm whether this material belongs to the recent species or not.

Order Squaliformes Goodrich, 1909

Family Centrophoridae Bleeker, 1859

Genus Centrophorus Müller \& Henle, 1837

Centrophorus aff. granulosus (Bloch \& Scheinder, 1801)

Material: 42 teeth. (Fig. 2-1)

The lower teeth are broad and strongly compressed labiolingually with a very large cusp pointing to the rear. The distal heel has a convex shape. On the labial face (Fig. 21a), the apron is quite developed with a base broader than its extremity and many small foramina are present on both sides. The mesial cutting edge is convex and may be serrated or smooth. The mesiolabial depression of the root is well marked like the distolingual depression. A welldeveloped uvula with small mesial foramina is present on the lingual face (Fig. 2-1b). The infundibulum opens beneath the uvula, at the level of the well-developed transverse lingual bulge, and is followed by a more or less marked groove toward the basal edge of the root. The upper tooth has a narrower and more erect cusp than the lower teeth. The distal heel is well separated from the main cusp. The apron is broader at its base. On each side, there are two small foramina. On the lingual face there is a small uvula, which is not well marked. Beneath the uvula, there are two axial foramina followed by a slight groove.

Remarks. The presence of a slightly serrated mesial cutting edge and absence of fold on the uvula are indicative of the living species Centrophorus granulosus. This species is widespread in the Miocene sediments of Vaucluse, from the Early to Late Miocene (Cappetta et al. 1967; Ledoux 1972; Cappetta 1975; Brisswalter 2009).

Genus Deania Jordan \& Snyder, 1902

Deania aff. calceus (Lowe, 1839)

Material: 10 teeth. (Fig. 2-2, 2-3)

Compared to Centrophorus, lower teeth of Deania are more compressed labiolingually and the crown is narrower. There is no serration on the mesial cutting edge. On the labial face (Fig 2-2a), the apron is very wide and thick, but its limits are slightly marked from the root. On each side of the apron, there are two well-developed marginal foramina. The labial depression is well marked. On the lingual face (Fig. 2-2b), the uvula is well marked but small and is flanked by marginal foramina, which reappear beneath the straight bulge and may be followed by a slightly marked groove. The upper teeth (Fig. 2-3) have a straight and high cusp. The apron is broad with a well-developed marginal foramen on each side. The crown has both distal and mesial heels. Teeth differ from those of Centrophorus by the reduction of the uvula on the lingual face. The lingual transversal bulge is well developed and bears a foramen. At its end, there is another small foramen followed by a slightly marked groove. The root is large at the base of the crown and thin at its basal edge.

Remarks. The number and position of the foramina on the lingual face of these teeth are distinctive of genus Centrophorus and indicative of the recent species Deania calceus. The remains of this genus are very rare in the fossil record but they have been already observed in the bathyal deposits of the Lower and Middle Miocene of Vaucluse (Cappetta et al. 1967; Ledoux 1972).

Family Dalatiidae Gray, 1851

Genus Isistius Gill, 1865

Isistius triangulus (Probst, 1879)

Material: 295 lower teeth. (Fig. 2-4) 
This species is represented by numerous teeth, all belonging to the lower jaw. All the dental files are represented, from the anteriors to the commissurals. The anterior and antero-lateral teeth are very compressed labiolingually and have a very large triangular symmetric crown. The mesial cutting edge is thin, translucent and weakly serrated. On the labial face, the apron is made of a thin layer of enamel, with a poorly marked limit. The layer ends behind a "button-hole" which divides the root into two lobes. On the root, square or rectangular in shape, there is a foramen on the top of the "button-hole". The commissural teeth (Fig. 2-4) are asymmetrical and have a poorly defined distal heel. The "button-hole" is very low and the external groove is oblique.

Remarks. The Neogene species I. triangulus differs from the Palaeogene species I. trituratus Winkler 1874 by the lower position of the "button-hole" on the labial face of the root and the serrated cutting edges (Ledoux 1972). The species I. triangulus is very common in the Miocene deposits of north Hemisphere, including the south of France from Hérault (Cappetta 1970) to Vaucluse (Ledoux 1972).

Genus "Oligodalatias" Welton, 1979

"Oligodalatias sp."

Material: 2 lower teeth. (Fig. 2-5)

The material consists of two poorly preserved teeth, reduced to the crown. Very close to the genus Squaliolus, these teeth differ, however by a mesial and a distal cutting edge strongly serrated. On the distal side there is a heel separated to the main cusp by a notch.

Remarks. This genus was described for the first time by Welton (1979) with two species: "Oligodalatias" jordani from the Middle Oligocene of the Pittsburg Bluff Formation (Colombia County, Oregon, USA) and "Oligodalatias" roederi from the Middle Eocene of the Ardath Formation (San Diego County, California, USA). If the oldest species Oligodalatias roederi was recently synonymised to Squaliodalatias weltoni (Adnet et al. 2006), our material is reminiscent of the second one: "Oligodalatias" jordani. Even if it is an unpublished nomen nudum of Welton (1979), we refer the teeth of Mazan to this genus, pending supplementary material. This invalid genus was already recorded from the Aquitanian of southern France by Cappetta (1970, plate 7, Fig. 8-9) as an indeterminate Squaliformes and by Ledoux (1972, Fig. 12) as belonging to a new species of Squaliolus.

Genus Squaliolus Smith \& Radcliffe, 1912

Squaliolus schaubi (Casier, 1958)

Centroscymnus schaubi (Casier, 1958)

Material: 3 lower teeth. (Fig. 2-6)

In this genus, teeth have a crown with a cusp strongly bent towards the rear. The mesial and the distal cutting edges
Fig. 2 1: Centrophorus aff. granulosus (scale: $1 \mathrm{~mm}$ ), lower anterior tooth, a: labial view; b: lingual view. (MAZ 1); 2-3: Deania aff. calceus (scale: $1 \mathrm{~mm}$ ), lower anterior tooth, a: labial view; b: lingual view; 3 : upper tooth, labial view. (MAZ 2; MAZ 3); 4: Isistius triangulus (scale: $1 \mathrm{~mm}$ ), commissural teeth, a: labial view; b: lingual view. (MAZ 4); 5: “Oligodalatias" sp. (scale: $1 \mathrm{~mm})$, lower anterior tooth, lingual view. (MAZ 5); 6: Squaliolus schaubi (scale: $1 \mathrm{~mm}$ ), lower anterior teeth, a: lingual view; b: labial view. (MAZ 6); 7: Pristiophorus suevicus (scale: $1 \mathrm{~mm}$ ), rostral tooth, profile. (MAZ 7); 8: Squatina subserrata (scale: $1 \mathrm{~mm}$ ), lateral tooth, a: labial view; b: lingual view. (MAZ 8); 9: Alopias aff. superciliosus (scale: $5 \mathrm{~mm}$ ), lateral tooth, a: labial view; b: lingual view. (MAZ 9); 10: Carcharoides catticus (scale: $5 \mathrm{~mm}$ ), upper lateral tooth, a: lingual view; b: labial view. (MAZ 10); 11: Cosmopolitodus hastalis (scale: $5 \mathrm{~mm}$ ), lateral tooth, a: labial view; b: lingual view. (MAZ 11); 12: Mitsukurina lineata (Scale: $5 \mathrm{~mm}$ ), anterior tooth, a: labial view; b: profile; c: lingual view. (MAZ 12)

are smooth and have a convex shape. We also observe the presence of a well-developed distal heel. The apron is broad, flat and spreads on all the surface of the labial face (Fig. 2-6b). The apron is separated into two unequal lobes on each side of the median labial foramen. The labial depression of the root is well marked. On the lingual face (Fig. 2-6a), the crown-root boundary stops at the level of the relatively large median lingual foramen. The lingual depression is well developed but its edges are not well marked. The basal part of root lacks on our material.

Remarks. The absence of lingual marginal foramina on the lingual face of root allows to assign these teeth to S. schaubi. This genus is very rare in the fossil record (Casier 1958, 1966; Barthelt et al. 1991) and was only found in Palaeogene and Neogene deep-water deposits. This species was reported in the deposits of the Early and Middle Miocene of southern France (Cappetta 1970; Ledoux 1972).

Order Pristiophoriformes Berg, 1958

Family Pristiophoridae Bleeker, 1859

Genus Pristiophorus Müller \& Henle, 1837

Pristiophorus suevicus (Jaekel, 1890)

Material: 1 rostral tooth. (Fig. 2-7)

This rostral tooth is long and thin with a sword shape. It consists of a basal peduncle and a long, flat cap more or less curved to the rear. The peduncle is slightly smaller than the crown. The cap is translucent and reveals the internal nutritive ducts. The base of the peduncle is wider than the top, and in basal view there is a deep concavity in the form of funnel which contains the pulp of the tooth.

Remarks. P. suevicus, recovered from the Miocene of southern Germany (Jaekel 1890; Barthelt et al. 1991), is uncommon in the Miocene sediments of southern France (Cappetta 1987). Nevertheless, it was also recorded from a rostral tooth, in the Middle Miocene deposits of "Cabrières d'Aigues" (Brisswalter 2009). 


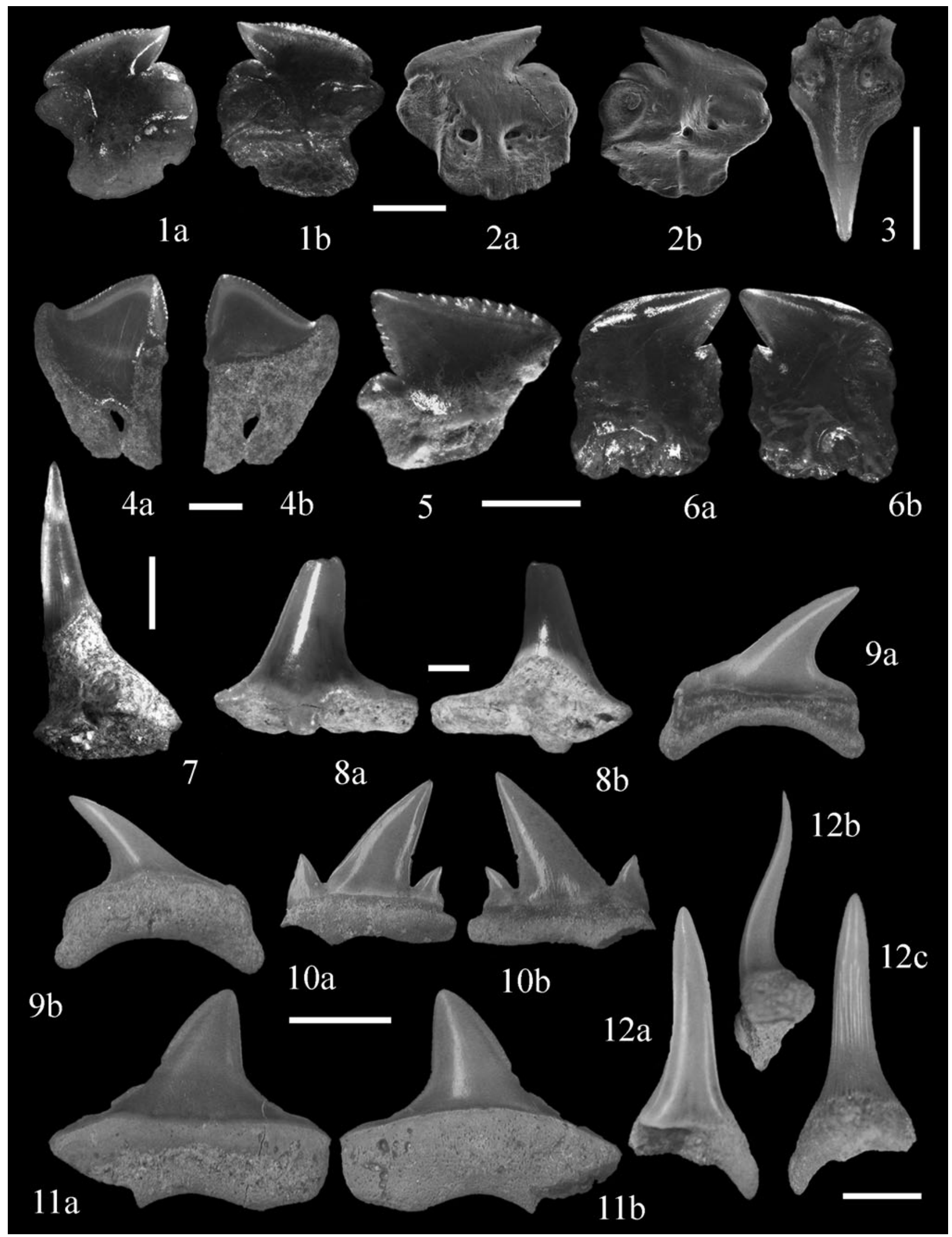


Order Squatiniformes Buen, 1926

Family Squatinidae Bonaparte, 1838

Genus Squatina Dumeril, 1806

Squatina subserrata Münster, 1846

Material: 1 tooth. (Fig. 2-8)

The single tooth is poorly preserved. The crown, straight and high, has a triangular outline in labial view and is perpendicular to the flattened root. The cusp is slightly bent lingually. The cusp presents at its base an enameled expansion (Fig. 2-8a), forming a distinct rounded apron. The lingual face (Fig. 2-8b) of the crown is more convex than the labial face. On each side of the cusp there are welldeveloped heels. The cutting edges are sharp and extend on the two heels. The root is very spread lingually and presents a well-marked protuberance. At the junction between the crown and the protuberance of the root, there are numerous small foramina. The basal face of the root is flat with a well-marked median triangular depression.

Remarks. If this species is well recorded in the Miocene of Europe and North America, this taxon is relatively scarce in southern France. However, it was recorded by Cappetta $(1973,1987)$ in the Early Burdigalian of "Lespignan" (Hérault) and in the Middle Miocene of "Cabrières d'Aigues" (Brisswalter 2009).

Order Lamniformes Berg, 1958

Family Alopiidae Bonaparte, 1838

Genus Alopias Rafinesque, 1810

Alopias aff. superciliosus (Lowe, 1840)

Carcharias superciliosus Lowe, 1840

Material: 1 tooth. (Fig. 2-9)

This very lateral tooth has a triangular, high and slender cusp, which overhangs the root in labial view. The crown bends toward the rear. The cutting edge is more developed on the distal side than on the mesial side. The labial face of crown is relatively flat contrary to the lingual face, which is much cambered. The base of the crown distinctly overhangs the labial face of the root, which is massive and transversely elongated, with two well-defined lobes. The mesial lobe of the root is slightly longer than the distal lobe. The basal face bears a poorly marked groove.

Remarks. This off-shore living species is known since the Early Miocene (e.g. Case, 1980; Purdy et al. 2001) but appears in the Middle Miocene deposits of southern France (Cappetta 1987). Brisswalter (2009) described the dental remains of a second extant species of Alopias, A. aff. vulpinus Bonnaterre 1788 in "Cabrières d'Aigues" (Vaucluse, southern France).

Family Cetorhinidae Gill, 1862

Genus Cetorhinus Blainville and de, 1816

Cetorhinus parvus Leriche, 1908

Material: Some fragments of gill-rakers.
The fossil remains of this genus are essentially represented by isolated fragments of gill-rakers. These gill-rakers are laterally flattened, curved with a hatchet-shaped basal part extending by a long and slender rod. These fragments are entirely covered by enameloid.

Remarks Our remains may be attributed to the OligoMiocene species $C$. parvus instead of the living species C. maximus Gunner 1765 as commonly accepted. Although this genus was first identified in the fossil state based on gill-rakers, some oral teeth were found in "Cabrières d'Aigues" (Brisswalter 2009). The genus was also recorded from the Middle Miocene of "Bonpas" (Cappetta et al. 1967). Cappetta and Ledoux (1970) observed that the fragments of branchioctenii collected in the Mediterranean fossil deposits are usually those of young individual as are those collected at "Mazan".

Family Lamnidae Müller \& Henle, 1838

Genus Carcharoides Ameghino, 1901

Carcharoides catticus (von Philippi, 1846)

Otodus catticus von Philippi, 1846

Lamna cattica, in Cappetta, 1970

Material: 4 teeth. (Fig. 2-10)

These teeth are characterized by a high cusp, large at its base and bent toward the rear. The cutting edges extend on the entire height of the main cusp and are smooth. On both sides of the main cusp we note the presence of a well developed, high, strong and sharp accessory cusplet. The mesial cusplet is bigger and straighter than the distal cusplet, which bents toward the rear like the main cusp. The two cusplets bear more or less marked cutting edges. The root is very thin and flat. On its basal face, there is the trace of a groove.

Remarks. It is the first evidence of this taxon in the Vaucluse area. It was previously reported from the Early Burdigalian of Hérault (Cappetta 1970) and elsewhere in North Hemisphere during Oligocene (e.g. Müller 1983, 1999) and Miocene (e.g. Bollinger et al. 1995; Purdy et al. 2001).

Genus Cosmopolitodus Glückman, 1964

Cosmopolitodus hastalis (Agassiz, 1843)

Isurus hastalis Agassiz, 1843

Material: 1 tooth. (Fig. 2-11)

This tooth is very stocky and has a low triangular crown. The cusp has a relatively flat labial face and a clearly convex lingual face. The cusp bends slightly toward the rear. The base of the cusp spreads marginally on the lobes of the root. The cutting edges of the cusp are completely smooth and continue to the heels. The root is well developed and has a massive aspect with two expanded but poorly differentiated lobes. 
Remarks. Distributed in the Mio-Pliocene worldwide deposits, the occurrence of $C$. hastalis was previously recorded from Hérault (Cappetta 1970) and "Cabrières d'Aigues" (Brisswalter 2009).

Family Mitsukurinidae Jordan, 1898

Genus Mitsukurina Jordan, 1898

Mitsukurina lineata (Probst, 1879)

Material: 288 teeth. (Fig. 2-12)

The anterior teeth have a slender and high crown, with a sigmoid shape in profile view (Fig. 2-12b). The labial face (Fig. 2-12a) is relatively flat or even slightly convex, while the lingual face is strongly convex. The enameloid of the lingual face (Fig. 2-12c) is marked by strong folds on its surface. These folds are parallel in the lower part of the crown and more flexuous toward the apex where they disappear. The heels are very short and abrupt, with secondary cusplets present or not. The root is well developed with two lobes. The lateral teeth have shorter cusps, with more developed oblique heels compared to the anterior teeth. The root has lobes more spread laterally and a deep groove on its basal face. There is often a pair of small marginal cusplets.

Remarks. Originally described by Probst (1879) in the Early Miocene of SW Germany, this species is abundant in bathyal Miocene deposits in Vaucluse (Joleaud 1912; Cappetta 1975, 1987) and other Alpine Foreland basins (Cappetta 1987; Bollinger et al. 1995).

Family Odontaspididae Müller \& Henle, 1839

Genus Carcharias Rafinesque, 1810

Carcharias aff. acutissima (Agassiz, 1843)

Odontaspis contortidens Agassiz, 1843

Chiloscyllum fossili Probst, 1879

Material: 33 teeth. (Fig. 3-1, 3-2)

The lateral teeth (Fig. 3-1) have a high and slender cusp, which is slightly bent toward the rear. The cusp is very broad at the base and overhangs the root on the labial face. The cusplets are well defined and more developed than those of the anterior teeth. On the more lateral teeth, cusplets have a triangular shape and remind those of the genus Carcharoides discussed previously. The root is very long with two well-developed lobes, separated from each other by a deep groove. The anterior teeth have a more straightened and slender cusp flanked by small, sharp cusplets. The cutting edge is well developed. The parasymphyseal teeth, much smaller than the laterals and the anteriors, have a crown with a very pronounced sigmoid profile. On each side, there is a small cusplet. The very massive root has fused lobes and a strong lingual protuberance. On the lingual face of some lateral, anterior and parasymphyseal teeth, enameloid is marked by many irregular folds, more or less salient, spreading from the base of the crown to the half part of its height. This feature depends of the specimen and the position on the jaw and does not allow a specific separation (Antunes and Jonet 1970). Commissural teeth (Fig. 3-2) have a very stocky crown with or without lateral cusplet. The root is very large, sometimes larger than the crown, and has a basal flat face with a deep groove.

Remarks. In 1912, Joleaud reported two species from Vaucluse, Odontaspis contortidens Agassiz 1843 and Chiloscyllum fossile Probst 1879 which were partly assigned afterward to Odontaspis acutissima by Cappetta $(1969,1970)$. This worldwide species is very abundant in the Miocene deposits of southern France (Brisswalter 2009).

Carcharias sternbergensis Reinecke, Moths, Grant \& Breitkreuz, 2005

Odontaspis molassica Joleaud, 1912

Material: 11 teeth.

The teeth of this species differ from the previous one by a thin and slender crown with a sigmoid profile. The crown is smooth on both sides. The cutting edges disappear in the lower third of the crown. The labial and the lingual face have a convex shape giving to the base a subcircular section. The root is absent on our material.

Remarks. Teeth assigned to Odontaspis molassica Probst 1879 in the southern Rhodanian basin (Joleaud 1907, 1912) and in Hérault (Cappetta 1970) were recently synonymised with $C$. sternbergensis by Cappetta (2006).

Order Carcharhiniformes Compagno, 1973

Family Carcharhinidae Jordan \& Evermann, 1896

Genus Carcharhinus Blainville, 1816

Carcharhinus priscus (Agassiz, 1843)

Sphyrna prisca Agassiz, 1843

Carcharhias (Aprionodon) stellatus Probst, 1878

Carcharhias (Aprionodon) brevis Probst, 1878

Carcharhinus (Hypoprion) lusitanicus Jonet, 1966 (in part)

Carcharhinus priscus, in Cappetta, 1970

Material: 60 teeth. (Fig. 3-3, 3-4)

The upper teeth (Fig. 3-4) have a narrow triangular crown. The cusp is well developed and bent toward the rear. The cutting edges are serrated only on their lower part. On each side of the cusp there is a well-developed heel. The distal heel is sometimes separated from the cusp by a notch. Both heels bear stronger serration than cusp. The root is flat and has a lingual protuberance bearing a deep clear groove. The lower teeth (Fig. 3-3) have a narrower cusp, bent toward the inside of the mouth. The cutting edges are smooth, as the two well-separated heels. The root is low and mesiodistally elongated.

Remarks. Teeth of Carcharhinus are very abundant in the Miocene deposits of southern France with two species 
well represented, C. elongatus Leriche, 1910 (Leriche 1957; Cappetta 1970) and mainly C. priscus (Cappetta 1969, 1970, 1987; Brisswalter 2009). Purdy et al. (2001) claimed that teeth of C. priscus (pl. 13: Figs. 8-19) described by Cappetta (1970) are in fact synonym of the extant species $C$. brachyurus Günther, 1870. The specific status of these fossil forms is still sufficiently uncertain so our teeth are attributed to $C$. priscus pending further analysis.

Genus Galeocerdo Müller \& Henle, 1837

Galeocerdo anduncus Agassiz, 1843

For the synonymy, see Cappetta (1970:50-51)

Material: 7 teeth. (Fig. 3-5)

The teeth possess a broad triangular and high cusp, which leans toward the rear. The cutting edge is incised by small serrations, and the teeth lack a mesial heel. The distal cutting edge is shorter and straight, marked by serrations. The distal heel is separated from the crown by a deep notch and presents a cutting edge with well-marked serration decreasing toward the rear. The labial face is flat whereas the lingual face is clearly convex. The root is thick and possesses a well-developed bulge.

Remarks. This worldwide species was reported in the Miocene deposits of the Rhone valley by Leriche (1906), Joleaud (1912) and Brisswalter (2009). In addition, Cappetta $(1969,1970,1987)$ recorded this species from the contemporaneous Hérault deposits.

Genus Isogomphodon Gill, 1862

Isogomphodon acuarius (Probst, 1879)

Alopecias acuarius Probst, 1879

Carcharhinus (Aprionodon) lerichei, in Jonet, 1966

Aprionodon acuarius, in Cappetta, 1970

Material: 8 teeth. (Fig. 3-6)

Teeth present a slight sigmoid curved crown. The enameloid is totally smooth. The cusp leans slightly toward the inside of the mouth. The cutting edges spread to the base of the crown and are completely smooth. The heels are well developed, elongated and sub-horizontal and do not share any separation from cusp. The root is almost horizontal with two lobes very enlarged and rounded extremities. On the median protuberance of the lingual face of the root (Fig. 3-6b) a well-marked groove appears.

Remarks. This species, common in Miocene of north Atlantic and Mediterranean, was reported by previous authors (Leriche 1906; Priem 1912) and by Cappetta (1970) from the Miocene deposits of the Rhone Valley. Cappetta (1970) described Isogomphodon caunellensis, from the Late Burdigalian of the region of Montpellier (Hérault) which differs from I. acuarius by larger teeth with a wider cusp.
Fig. 3 1-2: Carcharias aff. acutissima (scale: $5 \mathrm{~mm}$ ), 13: lateral tooth, a: labial view; b: lingual view; 14: commissural tooth, lingual view. (MAZ 13; MAZ 14); 3-4: Carcharhinus priscus (scale: $5 \mathrm{~mm}$ ), 3 : lower tooth, a: labial view; $b$ : lingual view; 4 : upper tooth, a: lingual view; b: labial view. (MAZ 15; MAZ 16); 5: Galeocerdo aduncus (scale: $5 \mathrm{~mm}$ ), anterior tooth, a: labial view; b: lingual view. (MAZ 17); 6: Isogomphodon acuarius (scale: $1 \mathrm{~mm}$ ), lateral tooth, a: labial view; $\mathrm{b}$ : lingual view. (MAZ 18); 7: Rhizoprionodon ficheuri (scale: $1 \mathrm{~mm}$ ), lateral tooth, a: labial view; b: lingual view. (MAZ 19); 8-9: Pachyscyllium aff. dachiardii (scale: $1 \mathrm{~mm}$ ), 8: anterior tooth, a: labial view; b: lingual view; 9: lateral tooth, a: occlusal view; b: lingual view. (MAZ 20; MAZ 21); 10-11: Scyliorhinus cf. joleaudi (scale: $1 \mathrm{~mm}$ ), 10: lateral tooth, a: lingual view; b: labial view; 11 : anterior tooth, a \& b: labial view; c: lingual view. (MAZ 22; MAZ 23); 12: Sphyrna arambourgi (scale: $5 \mathrm{~mm}$ ), lateral tooth, a: lingual view; b: labial view. (MAZ 24)

Genus Rhizoprionodon Whitley, 1929

Rhizoprionodon ficheuri (Joleaud, 1912)

Carcharias (Physodon) ficheuri Joleaud, 1912

Physodon miocanenicus Jonet, 1966

Scoliodon dentatus Jonet, 1966 (in part)

Scoliodon taxandriae Jonet, 1966 (in part)

Material: 28 teeth. (Fig. 3-7)

The teeth have a small size with a cusp bent toward the rear. The base of the crown is rather extended, particularly on the mesial edge, where the heel is not differentiated. The distal heel is high, unserrated with a rounded outline in labial view. On the labial face (Fig. 3-7a), the crown slightly overhangs the root. The mesial cutting edge is convex and smooth. The root is low and presents on its lingual face, a protuberance where a distinct deep groove appears.

Remarks. This species is relatively abundant in the Middle and the Late Miocene of southern France (Hérault, Cappetta 1970; Vaucluse, Joleaud 1912; Brisswalter 2009). It also occurs, but more rarely in the Miocene of Belgium (Leriche 1926) and North America (Müller 1999).

Family Hemigaleidae Hasse, 1879

Genus Paragaleus Budker, 1935

Paragaleus aff. pulchellus (Jonet, 1966)

Galeorhinus pulchellus Jonet, 1966

Material: 1 tooth.

The single example of this species is represented by a fragment of crown, probably from a lower tooth. The cusp is erect and presents a concave mesial cutting edge. On its distal side, there is a small sharp cusplet which composes the distal heel. The root is totally lacking.

Remark. Due to the poor quality of material, the identification of this species is uncertain. However, this species was reported by Cappetta (1970) in the Middle Miocene of Hérault and by Brisswalter (2009) in the Middle Miocene of "Cabrières d'Aigues" (Vaucluse). Both figures show similar features which support the referral of our tooth to this species. 


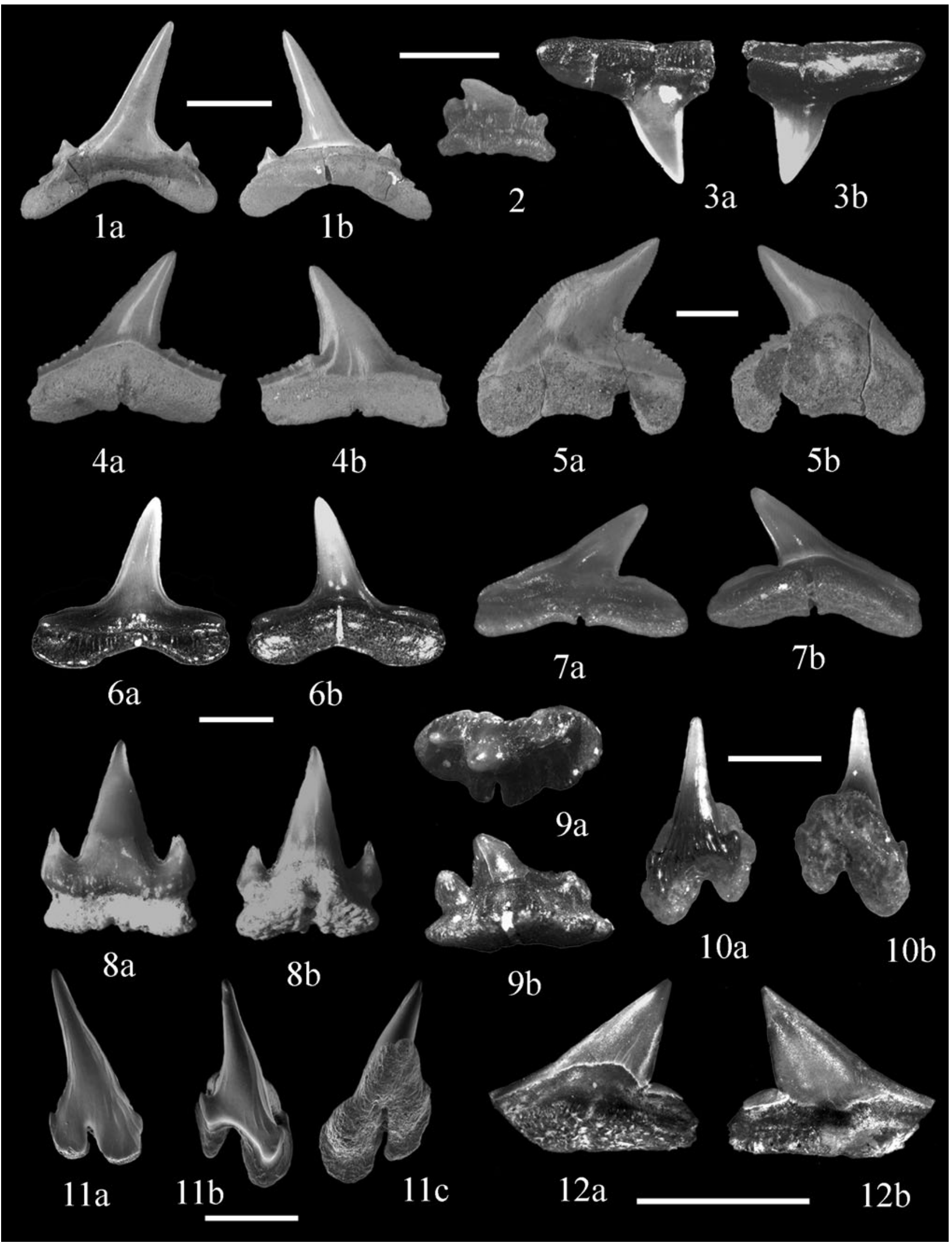


Family Scyliorhinidae Gill, 1862

Genus Pachyscyllium Reinecke, Moths, Grant \& Breitkreuz, 2005

Pachyscyllium aff. dachiardii (Lawley, 1876)

Scyliorhinus dachiardi Lawley, 1876

Scyliorhinus distans Probst, 1879 (in part)

Premontreia dachiardi, in Cappetta, 2006

Material: 83 teeth. (Fig. 3-8, 3-9)

The main cusp is slender and straight with a sigmoid profile. The lingual face is more convex than the labial. The cusp presents a transverse basal bulge overhanging the root labially. This bulge bears sometimes parallel folds more or less marked (Fig. 3-9a). The cusp is slightly bent toward the inside of the mouth in lateral files. On each side of cusp there is one pair of sharp and stocky cusplets. The cutting edges are continuous from cusp to lateral cusplets. The root presents a flat basal face and bears a strong lingual protuberance. The root is divided by a deep groove.

Remarks. Reported by Cappetta (1970, 1987; Cappetta and Nolf 1991; Brisswalter 2009), this taxon is common in the Miocene deposits of southern France.

Genus Scyliorhinus Blainville, 1816

Scyliorhinus cf. joleaudi Cappetta, 1970

Material: 10 teeth. (Fig. 3-10, 3-11)

These teeth are small with a very large root. The main cusp is very straight, slender and sharp, bending toward the rear and toward the inside of the mouth. The cutting edges are not well differentiated. The base of labial face (Fig. 3-10a) of the crown largely overhangs the lobes of the root and bears small more or less marked folds. On each side of the main cusp there are small accessory cusplets. The root is bulky with a massive lingual protuberance. The very spread basal face of the root does not present a groove. The lingual protuberance bears a small medio-lingual foramen.

Remarks. Some of our teeth (Fig. 3-11) are slightly different from the others by their labial smooth and flat face as the material type of $S$. joleaudi. This morphology, discovered in the Langhian deposits of Hérault (Cappetta 1970) also occurs in the site of "Cabrières d'Aigues", Vaucluse (Brisswalter 2009) and in Portugal (Antunes et al. 1999b). These are currently considered as resulting from intraspecific variation in tooth morphology, as observable in extant Scyliorhinus.

Family Sphyrnidae Gill, 1872

Genus Sphyrna Rafinesque, 1810

Sphyrna arambourgi Cappetta, 1970

Scoliodon taxandriae Jonet, 1966 (in part)

Material: 5 teeth. (Fig. 3-12)

The teeth are labio-lingually flattened with a triangular cusp bending toward the rear. The mesial heel is not
Fig. 4 1: Galeorhinus sp. (scale: $1 \mathrm{~mm}$ ), antero-lateral tooth, labial view. (MAZ 25); 2: Rhynchobatus pristinus (scale: $1 \mathrm{~mm}$ ), lateral tooth, occlusal view. (MAZ 26); 3-4: Raja gentili (scale: $1 \mathrm{~mm}$ ), 3: anterior male tooth (MAZ 27), labial view; 4: anterior female tooth, lingual view (MAZ 28); 5-6: Dasyatis probsti (scale: $1 \mathrm{~mm}$ ), 5: female tooth (MAZ 29), lingual view; 6: male tooth, lingual view. (MAZ 30): 7: Dasyatis rugosa (scale: $1 \mathrm{~mm}$ ), female tooth, lingual view. (MAZ 31); 8-9: Taeniura aff. cavernosa (scale: $1 \mathrm{~mm}$ ), 8: female tooth, lingual view. (MAZ 32); 9: male tooth, lingual view. (MAZ 33); 10: Mobula pectinata (scale: $1 \mathrm{~mm}$ ), a: occlusal view; b: basal view. (MAZ 34); 11: Aetobatus arcuatus (scale: $10 \mathrm{~mm}$ ), upper tooth, occlusal view. (MAZ 35); 12: Myliobatidae indet. (scale: $10 \mathrm{~mm}$ ), part of median tooth, a: occlusal view; b: posterior view. (MAZ 36); 13: Plesiobatis sp. (scale: $10 \mathrm{~mm}$ ), lingual view. (MAZ 37)

differentiated, but a clear distal heel is separated from the cusp by a deep notch. The cutting edges are smooth. On the labial face (Fig. 3-12b), the basal limit of the crown is flat.

Remarks. In many previous works, there is confusion in teeth assigned to Sphyrna that often belong to Carcharhinus (Cappetta 1970, 1987). The genus Sphyrna is, however, represented in the Middle Miocene of southern France by two species, the living Sphyrna zygaena Linnaeus, 1758 (Cappetta 1970, 1987) and Sphyrna arambourgi (Cappetta 1970; Brisswalter 2009) distinct from the previous one by smaller teeth and no serrated cutting edges.

Family Triakidae Gray, 1851

Genus Galeorhinus Blainville, 1816

Galeorhinus sp.

Material: 9 teeth. (Fig. 4-1)

These small teeth are mainly represented by isolated crowns. The main cusp is high, bending toward the rear. The mesial cutting edge is slightly convex and not serrated. The distal heel is high and well developed and bears strong cusplets decreasing in size toward the distal edge. The first accessory cusplet is well separated from the main cusp.

Remarks. Two species, G. affinis Probst, 1878 and G. latus Storms, 1894, were reported by Cappetta (1970) in the Miocene of Hérault. Currently the first species is assigned to Chaenogaleus affinis Probst, 1879 and the second one to Physogaleus latus Storms, 1894 (see Cappetta 2006). More recently, Brisswalter (2009) reported the presence of G. goncalvesi Antunes et al. (1999a) at "Cabrières d'Aigues". However, the very fragmentary remains of Mazan do not permit a reliable specific determination.

Order Rajiformes Berg, 1940

Family Rhynchobatidae Garman, 1913

Genus Rhynchobatus Müller \& Henle, 1837

Rhynchobatus pristinus (Probst, 1877)

Pristis pristinus Probst, 1877

Material: 31 teeth. (Fig. 4-2)

The teeth have a massive appearance. The oral face of the crown may be differentiated into three different areas. The 


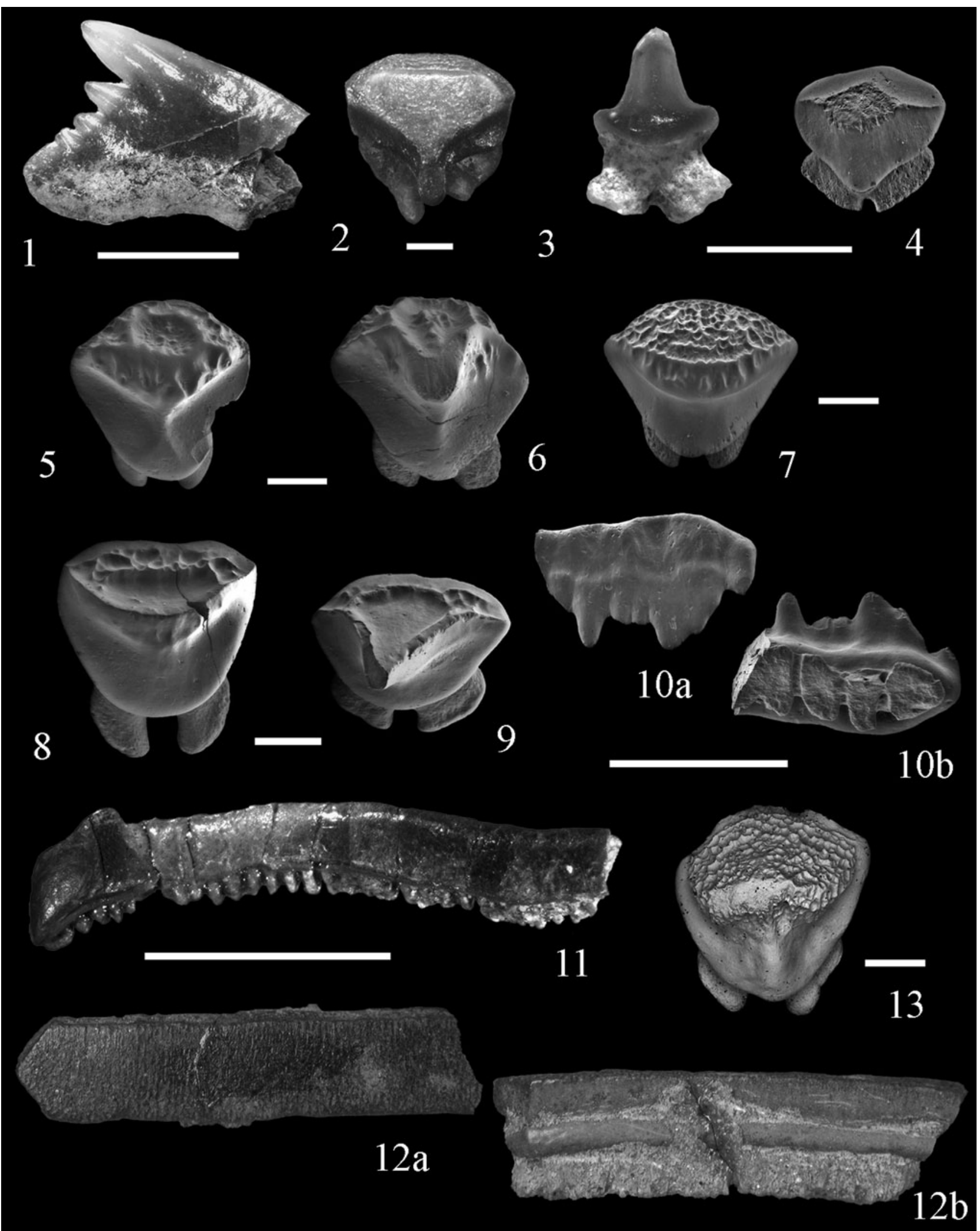


labial area is more or less convex. The occlusal has a triangular shape and is separated from the labial one by a clear straight crest. These two areas present a very precise ornamentation of enameloid granules. The lingual face of the crown is smooth and bears a well-developed enameled protuberance forming a long central uvula. The root is massive with two lobes well separated by a deep groove with two centrally positioned foramina. On the lingual face of the root, and on each side of the uvula, there is a wellmarked depression with a big margino-lingual foramen.

Remarks. The teeth of $R$. pristinus are relatively abundant in the Miocene deposits of Hérault (Cappetta 1970) and Vaucluse (Joleaud 1912; Brisswalter 2009) and elsewhere (e.g. Case 1980; Bollinger et al. 1995; Müller 1999).

Family Rajidae Bonaparte, 1831

Genus Raja Linnaeus, 1758

Raja gentili Joleaud, 1912

Material: 16 teeth. (Fig. 4-3, 4-4)

These teeth are very small and we note on this taxa a strong sexual heterodonty. The males (Fig. 4-3) possess teeth with a high and slender cusp. The labial face of the cusp is marked by a slightly sharp cutting edge. The crown overhangs the labial face of the root with a round-contoured and well-developed visor. The root is high with two large lobes separated by a small groove. The females (fig. 4-4) possess rounded teeth with a pyramidal crown. Both face of the crown are smooth. The crown is divised by a transversal median crest. On the lingual face, the uvula is not well marked. The root is massive with two well-defined lobes, separated by a deep groove.

Remarks. As the living Rajidae, preferentially inhabit the deep sea bottom in warm temperate and tropical realms, their fossils are not frequent in the coastal Miocene deposits of southern France. However, this species was recognized in some neritic deposits in Hérault (Cappetta 1970) but especially in the bathyal faunas of Vaucluse (Joleaud 1912; Cappetta et al. 1967; Brisswalter 2009).

Order Myliobatiformes Compagno, 1973

Family Dasyatidae Jordan, 1888

Genus Dasyatis Rafinesque, 1810

Many teeth of this genus occur in the deposits of Mazan and they are often badly preserved. Nevertheless, some rare teeth could be attributed to previously described species.

Dasyatis probsti Cappetta, 1970

Material: 6 teeth. (Fig. 4-5, 4-6)

The female teeth (Fig. 4-5) have a big size with a crown higher than the root. The transversal crest is broad and high. The median labial hollow has a sub-circular shape surrounded by a well-marked sharp edge. The lingual visor overhangs clearly the notch and the lobes of the root. The root is composed by two narrow lobes separated by a deep groove. In male teeth (Fig. 4-6), the posterior part of the crest stretches as a peak, the medio-external hollow is labiolingually stretched, the ornamentation is coarse and the crest bears strong folds.

Remarks. D. probsti differs from Taeniura cavernosa by the shape of the median labial hollow which is sub-circular for the first and triangular for the second. D. probsti is recorded in the Langhian of Hérault (Cappetta 1970) and was also mentioned by Brisswalter (2009) from the Serravallian of "Cabrières d'Aigues" (Vaucluse, southern France).

Dasyatis rugosa (Probst, 1877)

Raja rugosa Probst, 1877

Material: 7 teeth. (Fig. 4-7)

On female teeth (Fig. 4-7), the crown is low and has a transversal crest, broad and smooth, which overhangs the latero-posterior face. The labial face presents a narrow and extended laterally median hollow and has a reticulated ornamentation. The anterior visor is marked, on its upper part, by a bulge with a narrow groove. The root possesses two large lobes with a triangular shape in basal view. The teeth of males have a pointed crest bent toward the rear. The labial face is flat to slightly convex. It bears a more or less medial hollow and a reticulated ornamentation. The posterior visor has a concavity at the level of the mediolingual ridge.

Remarks. This species was described by Probst (1877) from the Early Miocene of SW Germany. Since, it was recorded by Cappetta (1970) and Brisswalter (2009) from the Miocene of Hérault and Vaucluse, respectively.

Genus Taeniura Müller \& Henle, 1837

Taeniura aff. cavernosa (Probst, 1877)

Raja cavernosa Probst, 1877

Dasyatis carvernosa, in Cappetta, 1970

Material: 21 teeth. (Fig. 4-8, 4-9)

Female teeth (Fig. 4-8) have a slightly convex labial face in profile view. The median hollow is labialy bordered by a distinct crest. This depression is deeper labially than lingually. The root is high with flattened lobes separated by a broad groove. The teeth of males are cuspidate (Fig. 4-9).

Remarks. In the fossil record this genus are often confused Dasyatis. Teeth of Taeniura differ from Dasyatis by a sharp transversal edge and an occlusal face quite concave. First recognised from the Messinian of Portugal (Antunes et al. 1999b), this genus appears relatively common in the Mediterranean deposits from the Langhian (Cappetta and Cavallo 2006).

Family Mobulidae Gill, 1893

Genus Mobula Rafinesque, 1810 
Mobula pectinata Cappetta, 1970

Material: 2 teeth. (Fig. 4-10)

The occlusal face (Fig. 4-10a) of the crown slopes toward the front. Its surface is bumpy. The anterior visor is well developed and widely overhangs the anterior face of the root. The transversal crest is cut out by long and pointed indentations directed backward. The lingual face of the crown has a concave profile. The posterior visor is less developed than the labial one. The root has a flat basal face (Fig. 4-10b) and is composed by four lobes.

Remarks. This fossil species of pelagic ray was described for the first time in the Langhian of Hérault (Cappetta 1970) like the other species M. loupianensis Cappetta, 1970. However, the species observed in Mazan differs from the last (M. loupianensis) by the presence of a multi-cusped transversal crest on tooth crown. It is the first occurrence of M. pectinata in the Miocene deposits of Vaucluse.

Family Myliobatidae Bonaparte, 1838

Genus Aetobatus Blainville, 1816

Aetobatus arcuatus (Agassiz, 1843)

Aetobatis arcuatus Agassiz, 1843

Material: 2 fragmentary teeth. (Fig. 4-11)

The fragments are those of upper teeth. The teeth are fairly rectilinear except the lateral edges which are curved towards the back. The length of the crown decreases toward the lateral extremities. The labial face of the teeth is sub-vertical while the lingual face is oblique. The separation between the crown and the root is made by a wellmarked posterior bulge. The root bends lingually and is composed of a succession of grooves and laminae. The root is higher than the crown in the median region of the file.

Remarks. The dental plate of this genus is composed by a single dental file. This fossil species of eagle ray is relatively common in the Early and Middle Miocene of Hérault (Cappetta 1970) and Vaucluse (Cappetta et al. 1967; Brisswalter 2009).

Myliobatidae indet.

Material: Many fragments. (Fig. 4-12)

The crown has hexagonal shape in occlusal view. The median file teeth are broader than long and generally rectilinear. The surface of the crown (Fig. 4-12a) is flat and is slightly convex in profile. On the lingual face (Fig. 4-12b), there is a well-developed bulge separating the crown from the massive root, which is composed by a succession of laminae and grooves in basal view. The lateral teeth have a hexagonal shape like the median teeth, but they are as long as broad.

Remarks. The very fragmentary state of our material precludes referral to a definite species and genera as Myliobatis Cuvier (ex Dumeril), 1816, Weissobatis Hovestdat
\& Hovestadt-Euler, 1999 Pteromylaeus Garman, 1913 or Aetomylaeus Garman, 1908.

Family Plesiobatididae Nishida, 1990

Genus Plesiobatis Nishida, 1990

Plesiobatis sp.

Material: 7 teeth. (Fig. 4-13)

The teeth have a globular shape, with a labial face separated from the lingual face by a smooth crest. The labial face presents a slightly reticulated ornamentation. A similar ornamentation can be observed on the apical half of the lingual face. The lower part of the labial visor is very flat and the visor is very sharp in profile view. The root is well developed but not very thick, with two lobes spread labiolingually and separated by a broad groove with a foramen. The basal face of the lobes is broad and very flat.

Remarks. The lack of a well-marked transversal crest and the presence on the lingual face of Plesiobatis of a well-marked mediolingual crest extending from the transversal crest to the posterior edge of the lingual visor allow differentiating Plesiobatis to Dasyatis, and especially to D. rugosa recovered in the deposit. Teeth of this genus have been found in the Langhian of southern France (Cappetta 2006).

\section{Paleoenvironmental inferences}

All the fossiliferous deposits of Vaucluse analysed here ("Saint Didier", "Bonpas", "Caumont", "Cabrières d'Aigues" and "Mazan") are coeval. Faunal differences are interpreted here as purely ecological. The new data provided by the "Mazan" fauna, together with those of the other Middle Miocene localities of Vaucluse previously reported in literature (Table 1) provides the first overview of the diversity of selachian fauna inhabiting the southern Rhodanian basin of the Mesogean realm during the transgressive cycle of the Langhian (see Besson et al. 2005). Based on the fauna from similar Vaucluse deposits, Cappetta et al. (1967) proposed an estimate of the sea level. Authors estimated that the sea have reached a depth of between 200 and $300 \mathrm{~m}$ at the Middle Miocene. The presence of many fossil representatives of extant pelagic and bathyal genera of selachian at "Mazan" (see Table 1); including the bathyal Squaliformes confirms the previously estimated depths. According to conclusion of Cappetta et al. (1967), the presence of numerous taxa as Aetobatus arcuatus and many Carcharhinidae at Mazan is characteristic of a quite warm water fauna.

In terms of diversity, the selachian fauna of "Mazan" is close to that of "Cabrières d'Aigues" reported by Brisswalter (2009) in the south of the Luberon Park (southern Vaucluse). Of the 40 species reported at "Cabrières 
Table 1 Fossil selachians recovered in Mazan and comparison with the other Middle Miocene localities of Vaucluse

\begin{tabular}{|c|c|c|c|c|c|c|}
\hline & (4) Saint Didier & (2) Caumont & (1) Bonpas & (3) Mazan & (5) Cabrières d'Aigues & Habitat of living representatives \\
\hline Paraheptranchias repens & & & $X$ & $X$ & & $27-1,000 *$ \\
\hline Hexanchus sp. & & & & $X$ & $X$ & $0-1,875$ \\
\hline Centrophorus aff. granulosus & & $X$ & $X$ & $\mathrm{X}$ & $X$ & $50-1,440$ \\
\hline Deania aff. calceus & $\mathrm{X}$ & $X$ & $X$ & $\mathrm{X}$ & & $70-1,470$ \\
\hline Isistius triangulus & & $X$ & $X$ & $X$ & $X$ & $0-3,500$ \\
\hline “Oligodalatias" sp. & & & $\mathrm{X}$ & $\mathrm{X}$ & & $0-4,000 *$ \\
\hline Squaliolus schaubi & & $X$ & $\mathrm{X}$ & $X$ & & $200-2,000$ \\
\hline Pristiophorus suevicus & & & $\mathrm{X}$ & $X$ & $X$ & $100-952$ \\
\hline Squatina subserrata & & & $X$ & $\mathrm{X}$ & $X$ & $0-494$ \\
\hline Alopias aff. superciliosus & & & $\mathrm{X}$ & $X$ & $X$ & $0-732$ \\
\hline Cetorhinus parvus & & & & $\mathrm{X}$ & $X$ & $0-904$ \\
\hline Carcharoides catticus & & & & $\mathrm{X}$ & & $0-1,000 *$ \\
\hline Cosmopolitodus hastalis & & & & $X$ & $X$ & $0-1,300 *$ \\
\hline Mitsukurina lineata & $X$ & & & $\mathrm{X}$ & & $270-960$ \\
\hline Carcharias aff. acutissima & & & $X$ & $\mathrm{X}$ & $X$ & $0-191$ \\
\hline Carcharias sternbergensis & & & $X$ & $\mathrm{X}$ & & $0-191$ \\
\hline Carcharhinus priscus & & & & $\mathrm{X}$ & $X$ & $0-430$ \\
\hline Galeocerdo anduncus & & & $X$ & $\mathrm{X}$ & $\mathrm{X}$ & $0-140$ \\
\hline Isogomphodon acuarius & & & & $\mathrm{X}$ & $X$ & $4-40$ \\
\hline Rhizoprionodon ficheuri & & & & $\mathrm{X}$ & $X$ & $1-100$ \\
\hline Paragaleus aff. pulchellus & & & & $\mathrm{X}$ & $X$ & $0-100$ \\
\hline Pachyscyllium aff. dachiardii & & & & $\mathrm{X}$ & $X$ & $0->2,000^{*}$ \\
\hline Scyliorhinus cf. joleaudi & & & & $\mathrm{X}$ & $X$ & $0-754$ \\
\hline Sphyrna arambourgi & & & & $\mathrm{X}$ & & $0-275$ \\
\hline Galeorhinus sp. & & & & $\mathrm{X}$ & & $2-471$ \\
\hline Rhynchobatus pristinus & & & $\mathrm{X}$ & $\mathrm{X}$ & $X$ & $0-65$ \\
\hline Raja gentili & & & $X$ & $\mathrm{X}$ & $X$ & $3-1,000$ \\
\hline Dasyatis probsti & & & & $X$ & $X$ & $0-480$ \\
\hline Dasyatis rugosa & & & & $\mathrm{X}$ & $X$ & $0-480$ \\
\hline Taeniura aff. cavernosa & & & & $X$ & & $0-500$ \\
\hline Mobula pectinata & & & & $X$ & & $0-100$ \\
\hline Aetobatus arcuatus & & & $X$ & $X$ & $X$ & $0-100$ \\
\hline Myliobatidae indet. & & & $\mathrm{X}$ & $X$ & $X$ & $0-200$ \\
\hline Plesiobatis sp. & & & $X$ & $\mathrm{X}$ & & $44-680$ \\
\hline
\end{tabular}

For Caumont, Bonpas and Saint-Didier, Ledoux, 1972; for Bonpas, Cappetta et al. 1967; for Cabrières d'Aigues, Brisswalter, 2009

The maximal depth range (in meter) of living representatives (species or genus) is compiled from Compagno et al. 2005; Kyne and Simpfendorfer 2007 and online data available at www.fishbase.org. * indicates that maximal depth range is that of the family

d'Aigues", 23 are present in Mazan (66\% taxa in common). Most of them belong to the order of Carcharhiniformes (e.g. Carcharhinus priscus, Galeocerdo aduncus, Isogomphodon acuarius or Scyliorhinus joleaudi). Living representatives of those forms live in neritic to pelagic environments (see Table 1) and indicates a shallow area close to the coastal zone (Brisswalter, 2009). Six taxa of batoid are newly reported compared to "Cabrières d'Aigues" (e.g. Rhynchobatus pristinus, Dasyatis rugosa or Aetobatus arcuatus) and their living representatives are distinctive of shallow water. The presence of pelagic
Lamniformes (e.g. Alopias superciliosus, Cetorhinus parvus, Cosmopolitodus hastalis) or pelagic ray (e.g. Mobula) testify of a more open environment than at "Cabrières d'Aigues". The site of "Bonpas" near Avignon, published by Ledoux (1972), has 16 species in common (48\%) with "Mazan". The main pool of taxa in common with "Mazan" belongs to the order of Squaliformes with Centrophorus granulosus, Deania calceus, "Oligodalatias", Isistius triangulus and Squaliolus schaubi. The presence of these forms is clearly characteristic of a relatively deep-sea environment (see Table 1) as indicated by the ecology of 
living representatives of $C$. granulosus or D. calceus that spend the majority of their life cycle at depths below $200 \mathrm{~m}$ (Kyne and Simpfendorfer 2007). Some of these taxa are also found in the deposits of "Caumont" and "Saint Didier" (Vaucluse) considered as deposited in deep-sea environment (Ledoux 1972). For instance, the Lamniformes Mitsukurina lineata, known at "Saint-Didier", is a good indicator of deep-sea deposits because its living representative $M$. owstoni only inhabits the bathyal sea bottom deeper than $200 \mathrm{~m}$ (Compagno 2001). Other newly recorded taxa from "Mazan" are in agreement with a deepsea origin of deposit (see Table 1) as Paraheptranchias repens, Hexanchus sp., Squaliolus shaubi, Pristiophorus suevicus, Raja gentili and Plesiobastis sp. (known at "Bonpas" too, Cappetta, pers. obs.). Finally, three groups dominate in "Mazan" deposits. The most important is the Carcharhiniformes with nine identified species, representing $27 \%$ of species present at the site. The other two groups are Lamniformes and Myliobatiformes, with seven species each, representing $20 \%$ of the association. These groups, comprising lot of epipelagic or epibenthic representatives today, support the idea of a relatively open sea with a near shore. On the other hand, the presence of numerous Squaliformes (i.e. 5 species constituting 14\% of species in the site), Hexanchiformes, Rajidae and fossil representativs of Mitsukurina suggest a deeper environment, as in "SaintDidier", "Bonpas" or "Caumont".

Such ecological incongruence could be explained by the peculiar topology of the ancient seafloor of this area. Besson et al. (2005) clearly demonstrated that the Langhian sandy marls ("Schlier" marls Formation) fill a large complex network of incised valleys resulting from deep fluvial incisions of the Rhodanian basin during the regressive cycle of the Late Burdigalian (see Fig. 1). The fossiliferous site of "Mazan" is precisely located near one of these submarine valleys. In such topological context, two alternatives hypothesis can explain why the fossil remains belonging to two different ecological associations could be mixed in the same place: either the deep water faunal elements were migrating up submarine canyons into shallow water by coastal upwelling, or the shallow water elements were being washed into deeper water by turbidity currents or slumping. No fine data concerning the sedimentology or tectonic are currently available to resolve definitively this question. However, the dental elements of the more neritic taxa are more badly conserved compared to those of the deeper representatives. This suggests that a minor part of material (e.g. Rhizoprionodon, Paragaleus, Rhynchobatus, some Dasyatidae and Myliobatidae) may have been slightly reworked and transported into deeper waters.

Starting from the faunal combination of the site of "Mazan" and data supplied from previous works on the deposits of Vaucluse (see Table 1), we can propose the environmental settings of deposit formation in "Mazan". These deposits correspond to those of an external platform and/or upper slope, relatively open with a great depth influence. Presence of teeth of the most neritic inhabitants could have been transported far offshore within the submarine valleys.

Looking at the faunal association of the site of "Cabrières d'Aigues", which also contains a significant assemblage, we note a similar grouping of dominant orders with the same proportions; Carchariniformes, 31\%; Lamniformes, $17 \%$; Myliobatiformes, $19 \%$ and Squaliformes, $13 \%$. This ecological similarity suggests that the environmental settings in "Mazan" were probably more similar with "Cabrières d'Aigues" than with the nearest localities ("Bonpas", "Caumont" and "Saint-Didier") considered as deposited in strict deepwater environments. Such spatial heterogeneities in the Middle Miocene selachian associations supply further arguments to consider that the continental shelf forming the southern Rhodanian basin during the Langhian was probably crenulated by numerous submarine canyons or valleys.

The new data provided by the fauna of "Mazan" allow a better understanding on the environment of the southern Rhodanian basin during the Middle Miocene but it would be interesting to better explore Miocene deposits of the Vaucluse and adjacent areas in order to more precisely redraw the outlines of Middle Miocene coasts.

Acknowledgments Authors are particularly grateful to the two anonymous reviewers who significantly improved the quality of the first draft, and to Isabelle Vea for her corrections of English.

\section{References}

Adnet, S., Cappetta, H., \& Reynders, J. (2006). Nouveaux genres de Squaliformes (Chondrichthyes) du Paléogène des Landes (SudOuest de la France). Paläontologische Zeitschrift, 80(1), 60-67.

Agassiz, L. (1843). Recherches sur les poissons fossiles. 3, $390+32$ P., $47 \mathrm{pl}$.

Ameghino, F. (1901). L'âge des formations sédimentaires de Patagonie. Anales de la Sociedad Cientifica Argentina, 51, $20-39+65-91$.

Antunes, M. T., Balbino, A. C., \& Cappetta, H. (1999a). A new shark, Galeorhinus goncalvesi nov. sp. (Triakidae, Carcharhiniformes) from the latest Miocene of Portugal. Tertiary Research, 19(3-4), 101-106.

Antunes, M.T., Balbino, A.C. \& Cappetta, H. (1999b). Sélaciens du Miocène terminal du bassin d'Alvalade (Portugal) Essai de synthèse. Ciênsas da Terra 13, 115-129.

Antunes, M. T., \& Jonet, S. (1970). Requins de l'Helvétien supérieur et $\mathrm{du}$ Tortonien de Lisbonne. Bulletin de l'Université de Lisbonne, 2, 120-280.

Barnard, K. H. (1925). A monography of the marine fishes of South Africa. Part I. Annals of the South African Museum, 21, 1-418.

Barthelt, D., Fejfar, O., Pfeil, F. H., \& Unger, E. (1991). Notizen zu einem Profil der Selachier Fundstelle Walbertsweiler im Bereich 
des miozänen Oberen Meeresmolasse Süddeutschlands. Münchner Geowissenschaftliche Abhandlungen, 19, 195-208.

Berg, L. S. (1940). Classification of fishes both recent and fossil. Trudy Zoological institut, Leningrad, 5, 85-517.

Berg, L.S. (1958). System der rezenten und fossilen Fischartigen und Fische (p. 310) Berlin: Deutsch Verlag Wiss.

Besson, D. (2005). Architecture du bassin Rhodano-provençal miocène (Alpes, SE France). Relations entre déformation, physiographie et sédimentation dans un bassin molassique d'avant-pays. (p. 449) Unpublish MSc thesis, Thèse de l'Ecole des Mines-Paris Tech, Paris.

Besson, D., Parize, O., Rubino, J. L., Aguilar, J. P., Aubry, M. P., Beaudoin, B., et al. (2005). Un réseau fluviatile d'âge Burdigalien terminal dans le Sud-Est de la France: remplissage, extension, âge, implications. Compte rendu de Geoscience, 337, 1045-1054.

Blainville, H.M.D. de (1816). Prodrome d'une nouvelle distribution systématique du règne animal. (pp. 105-112 + 121-124) Bulletin de la Société Philomathique, Paris 8.

Bleeker, P. (1859). Over eenige vischsoorten van de Zuidkustwateren van Java. Natuurkundig Tijdschrift voor Nederlandsch Indië, 19, 329-352.

Bloch, M.E. \& Scheinder, J.G. (1801). M.E. Blochii Systema Ichthyologiae iconibus ex illustratum. Post obitum auctoris opus inchoatum absolvit correxit, interpolativ J.G. Scheinder, Saxo. pp. 584 .

Bollinger, T., Kindlimann, R., \& Wegmüller, U. (1995). Die marinen Sedimente (jüngere OMM, St.Galler-Formation) am Südwestrand des Hörnlischüttung (Ostschweiz) und die palökologische Interpretation ihres Fossilinhaltes. Eclogae Geologica Helvetica, 88, 885-909.

Bonaparte, C. L. (1831). Saggio di una distribuzione metodica degli animali vertebrati. Giornale Arcadico di Scienze Lettere ed Arti, $52,155-189$

Bonaparte, C. L. (1838). Selachorum tabula analytica. Nuovi Annali Scienze naturali, Bologna, 2, 195-214.

Bonnaterre, J.P. (1788). Ichthyologie. Tableau encyclopédique et méthodique des trois règnes de la (pp. 215). Paris: Nature, pl. A-B + 1-100.

BRGM (1975). Carte Géologique au 1/50,000 n 941, Carpentras. BRGM Editions, 2-7159-1941-7.

Brisswalter, G. (2009). Inventaire des Elasmobranches (requins, raies, chimères) des dépôts molassiques du Sud-Luberon (Miocène supérieur), à Cabrières d'Aigues (Vaucluse) France (pp. 1-100). Courriers scientifiques du Parc Régional du Lubéron Hors Série: Apt.

Budker, P. (1935). Description d'un genre nouveau de la famille des Carcharhinidés. Bulletin du Muséum d'Histoire Naturelle. Paris, 2(7), 107-112.

Cappetta, H. (1969). L'Ichthyofaune (Euselachii, Teleostei) miocène de la région de Montpellier (Hérault). pp. 291. Unpublish MSc thesis, Thèse de Spécialité (Montpellier).

Cappetta, H. (1970). Les sélaciens du Miocène de la région de Montpellier. Palaeovertebrata Mémoire extraordinaire (pp. $1-140)$.

Cappetta, H. (1973). Les sélaciens du Burdigalien de Lespignan (Hérault). Géobios, 6, 211-223.

Cappetta, H. (1975). Les Sélaciens miocènes du midi de la France, répartition stratigraphique et bathymétrique (p. 90). $3^{\text {ème }}$ réunion annuelle des Sciences de la Terre, Montpellier.

Cappetta, H. (1987). Mesozoic and Cenozoic Elasmobranchii, Chondrichthyes II. 3B. In H.P. Schultze (Ed.), Handbook of Paleoichthyology (p. 193).

Cappetta, H. (2006). Elasmobranchii post-Triadici (index generum et specierum). In W. Riegraf (Ed.), Fossilium Catalogus I: Animalia 142 (p. 472). Backhuys Publish: Leiden.
Cappetta, H., \& Cavallo, O. (2006). Les Sélaciens du Pliocène de la région d'Alba (Piémont, Italie Nord-Ouest). Rivista Piemontese di Storia Natura, 27, 33-76.

Cappetta, H., Granier, J., \& Ledoux, J.-C. (1967). Deux faunes de Sélaciens du Miocène méditerranéen de France et leur signification bathymétrique. Comptes rendus sommaires des séances de la Société géologique de France, 7, 292.

Cappetta, H. \& Ledoux, J.C. (1970). Comparaison de la faune ichthyologique miocène avec la faune actuelle de Méditerranée. Journée ichthyologique C.I.E.S.M., Rome, pp. 21-23.

Cappetta, H., \& Nolf, D. (1991). Les sélaciens du Pliocène inférieur de Le-Puget-sur-Argens (Sud-Est de la France). Palaeontographica A, 218, 49-67.

Case, G. R. (1980). A selachian fauna from the Trent Formation; lower Miocene (Aquitanian) of eastern North Carolina. Palaeontographica, A, 171, 75-103.

Casier, E. (1958). Contribution à l'étude des poissons fossiles des Antilles. Schweizerische palaeontologische Abhandlungen, 74, $1-95$.

Casier, E. (1966). Faune ichthyologique $d u$ London Clay. $X I V+403 p$. London: Trust. British Museum (Natural History).

Compagno, L.J.V. (1973). Interrelationship of living elasmobranchs. In P.H. Greenwood, R.S., R.S. Miles \& C. Patterson (Eds.) Interrelationships of Fishes. Zoological Journal of the Linnaean Society, Supplement no.1-53, 15-98.

Compagno, L.J.V. (2001). Sharks of the world. An annotated and illustrated catalogue of shark species known to date. Volume 2. Bullhead, mackerel and carpet sharks (Heterodontiformes, Lamniformes and Orectolobiformes). FAO Species Catalogue for Fishery Purpose, No. 1 (Vol 2, pp. 1-8 + 1-269), Rome.

Compagno, L.J.V., M. Dando, \& S. Fowler. (2005). A field guide to the sharks of the world (pp. 1-368) London: Harper-Collins.

Cuvier, G. (1816). Le règne animal distribué d'après son organisation, pour servir de base à l'histoire naturelle des animaux et d'introduction à l'anatomie comparée. Paris Poissons, 2, 104-351.

de Buen, F. (1926). Catálogo ictiológico del Mediterráneo español y de Marruecos recopilando lo publicado sobre peces de las costas mediterránea y próximas del Atlántico (Mar de España) (p. 221). Madrid: Resultados de la Campaña internacional del Instituto Español de Oceanographía.

Demarcq, G. (1970). Etude stratigraphique du Miocène rhodanien. Mémoires du B.R.G.M., 61, 115-159.

Dumeril, A.M.C. (1806). Zoologie Analytique ou Méthode Naturelle de classification des animaux, rendue plus facile à l'aide de tableaux synoptiques, Paris.

Fischer, H. (1878). Note paléontologique sur la molasse de Cucuron. Bulletin de la Société Géologique de France, $3^{\text {ème }}$ série T-7, 221-222.

Garman, S. (1908). New Plagiostomia and Chimopnea. Bulletin of the Museum of Comparative Zoology, Harvard, 51, 249-256.

Garman, S. (1913). The Plagiostomia (Sharks, Skates and Rays). Memoirs of the Museum of comparative zoology, Harvard, 36, $1-528$.

Gignoux, M. (1960). Géologie stratigraphique (5th ed.) Paris: Masson et Cie.

Gill, T. N. (1862). Analytical synopsis of the order of Squali; and revision of the nomenclature of the genera. Annals of the Lyceum of Natural History of New-York, 7, 371-408.

Gill, T. N. (1865). Synopsis of the eastern American sharks. Proceedings of the Academy of Natural Sciences of Philadelphia, 16(5), 258-265.

Gill, T. N. (1872). Arrangement of the families of fishes, or classes Pisces, Marsipobranchii, and Leptocardii. Smithsonian miscellaneous collections, 5(2), 1-49.

Gill, T. N. (1893). Families and subfamilies of fishes. Memoirs of the National Academy of Science, 6, 127-138. 
Glückman, L.S. (1964). Class Chondrichthyes, Subclass Elasmobranchii. In D.V. Obruchev (Ed.), Fundamentals of Paleontology, Academia Nauk SSSR (Russian edition) (Vol. 11, pp.196-237) (pp. 292-352 in English translation, Jerusalem, 1967).

Goodrich, E.S. (1909). Vertebrata Craniata. I. Cyclostomes and fishes. In. E.R. LANKESTER (Ed.) A Treatise on Zoology (pp. XVI + 518), pt. 9, London.

Gray, J.E. (1851). List of the specimens of fish in the collection of the British Museum, Part 1. British Museum of Natural History (pp. 160)

Gunner, J. E. (1765). Brugden (Squalus maximus), Beskrvenen ved. J.E. Gunnerus. Det Trondhei Sel'skoe Skrif, 3, 33-49.

Günther, A. (1870). Catalogue of the fishes in the British Museum, 8, Catalogue of the Physostomi containing the families Gymnotidae, Symbranchidae, Muraenidae, Pegasidae and of the Lophobranchii, Plectognathi, Dipnoi, Ganoidei, Chondropterygii, Cyclostomata (p. 549). London: Leptocardii in the collection of the British Museum.

Hasse, J. C. F. (1879). Das natürliche System des Elasmobranchier auf Grundlage des Baues und der Entwicklung ihrer Wirbelsäule $(385+27$ pp). Jena: Gustav Fischer.

Hovestadt, D. C., \& Hovestadt-Euler, M. (1999). Weissobatis micklichi n. gen., n. sp., an eagle ray (Myliobatiforms, Myliobatidae) from the Oligocene of Frauenweiler (Baden-Württemberg, Germany). Paläontologische Zeitschrift, 73, 337-349.

Jaekel, O. (1890). Ueber die Systematische Stellung und über fossile reste der Gattung. Pristiophorus Zeitschrift der Deutschen Geologischen Gesellschaft, 42, 86-120.

Joleaud, L. (1907). Géologie et Paléontologie de la Plaine du Comtat et de ses abords. Description des terrains Néogènes. Mémoire de l'Académie du Vaucluse, 1, 1-254.

Joleaud, L. (1912). Géologie et Paléontologie de la Plaine du Comtat et de ses abords. Description des terrains Néogènes. Mémoire de l'Académie du Vaucluse, 2, 255-285.

Jonet, S. (1966). Notes d'ichthyologie miocène. II. Les Carcharhinidae. Boletim do Museu e Laboratório Mineralógico e Geológico da Faculdade de Ciências. Universidade de Lisboa, 10(2), 65-88.

Jordan, D. S. (1888). Description of two new species of fishes from South America. Proceedings of the Academy of Natural Sciences of Philadelphia, 39, 387-388.

Jordan, D. S. (1898). Description of a species of fish (Mitsukurina owstoni) from Japan, the type of a distinct family of Lamnoid sharks. Proceedings of the California Academy of Sciences, 3(1), 199-204.

Jordan, D. S., \& Evermann, B. W. (1896). Check-list of the fishes and fish-like Vertebrates of North and Middle America. Rept. U.S. Commnr Fish, 21, 207-584.

Jordan, D. S., \& Snyder, J. O. (1902). Descriptions of two news species of squaloid sharks from Japan. Proceedings of the United States National Museum, 25, 79-87.

Kyne, P. M. \& Simpfendorfer, C.A. (2007). A collation and summarization of available data on deepwater chondrichthyans: biodiversity, life history and fisheries. IUCN SSC Shark Specialist Group for the Marine Conservation Biology Institute (pp. 1-137).

Lawley, R. (1876). Nuovi Studi sopra ai Pesci ed Vertebrati fossili delle Colline toscane (p. 122).

Ledoux, J. C. (1972). Les Squalidae (Euselachii) miocènes des environs d'Avignon (Vaucluse). Documents des laboratoires de géologie de la faculté des sciences de Lyon, Notes et Mémoires, $52,133-175$.

Leriche, M. (1906). Révision de la faune ichthyologique des terrains néogènes du basin du Rhône. In Association Française pour Avancement des Sciences. Compte rendu de la $35^{\text {eme }}$ session, Lyon. Notes et Mémoires (pp. 335-352).
Leriche, M. (1908). Sur un appareil fanonculaire de Cetorhinus trouvé à l'état fossile dans le Pliocène d'Anvers. Compte Rendu Académie des Sciences, Paris, 146, 875-878.

Leriche, M. (1910). Les poissons oligocènes de la Belgique. Mémoires du Musée Royal d'Histoire Naturelle de Belgique, 5, 233-363.

Leriche, M. (1926). Les poissons tertiaires de la Belgique. IV. Les poissons néogènes. Mémoires du Musée Royal d'Histoire Naturelle de Belgique, 32, 367-472.

Leriche, M. (1957). Les Poissons néogènes de la Bretagne, de la Anjou et de la Touraine. Mémoire de la Société Géologique de France N.S., 36, 1-61.

Linnaeus, C. (1758). Systema Naturae, 10th edn (Vol. 1, pp. 230-338) Nantes \& Pisces.

Lowe, R. T. (1839). A supplement to a synopsis of the fishes from Madeira. Proceedings of the Zoological Society. London, 7(89), 76-92.

Lowe, R. T. (1840). Description of certain new species of Madeiran fishes, with additional information relating to those already described. Proceedings of the Zoological Society, London, 8, 36-39.

Müller, A. (1983). Fauna und Palökologie des marinen Mitteloligozäns des Leipziger Tieflandsbucht (Böhlener Schichten). Altenburger Naturwissenschaftliche Forschungen, 2, 1-152.

Müller, A. (1999). Ichthyofaunen aus dem atlantischen Tertiär des USA. Leipziger Geowissenschafteb, 9-10, 1-360.

Müller, J., \& Henle, F. G. J. (1837). Ueber die Gattungen der Haifische und Rochen, nach ihrer Arbeit: "Uber die Naturgeschichte der Knorpelfische". Bericht Akademie der Wissenschaften zu Berlin, 1, 111-118.

Müller, J., \& Henle, F. G. J. (1838). On the generic characters of cartilaginous fishes, with descriptions of new genera. Magazine of Natural History, new series, 2, 1-36.

Müller, J. \& Henle, F.G.J. (1839). Systematische Beschreibung der Plagiostomen, i-xxii +220 pp. Berlin.

Münster, G. G. (1846). Ueber die in der Tertiär-Formation des Wiener Beckens vorkommender Fisch Ueberreste, mit Beschreibung einiger neuen merkwürdigen Arten. Beiträge Petrefakten-Kunde, $7,1-31$.

Nishida, K. (1990). Phylogeny of the suborder Myliobatoidei. Mem. Fac. Fish. Hokkaido University, 37(1-2), 1-108.

Pfeil, F. H. (1981). Eine nektonische Fischfauna aus dem unteroligozänen schnöneker Fischschiefer des Galon Grabens in Oberbayern. Geologica Bavarira, 82, 357-388.

von Philippi, R.A. (1846). Tornatella abbreviata, Otodus mitis, Otodus catticus und Myliobatis testae. Palaeontographica, 1(1), 23-26.

Priem, F. (1912). Sur les poissons fossiles des terrains tertiaires supérieurs du Sud de la France. Bulletin de la Société Géologique de France série 4 t. XII, 213-245.

Probst, J. (1877). Beiträge zur Kenntniss der fossils Fische aus der Molasse von Baltringer. II. Batoidei A. Günther. Klein-und grosszahnige Rochen. Jahreshefte des Vereins für vaterländische Naturkunde in Württemberg, 33, 69-103.

Probst, J. (1878). Beiträge zur Kenntniss der fossils Fische aus der Molasse von Baltringer. Hayfische (Selachoidei A. Günther). Jahreshefte des Vereins für vaterländische Naturkunde in Württemberg, 34, 113-154.

Probst, J. (1879). Beiträge zur Kenntniss der fossils Fische aus der Molasse von Baltringer.Hayfische (Selachoidei A. Günther) (Schluss). Jahreshefte des Vereins für vaterländische Naturkunde in Württemberg, 35, 127-191.

Purdy, R.W., Schneider, V.P., Applegate, S.P., Mclellan, J.H., Meyer, R.L. \& Slaughter, B.H. (2001). The Neogene Sharks, Rays, and Bony Fishes from Lee Creek Mine, Aurora, North Carolina. Smithsonian Contribution to Paleobiology, 90, 71-202. 
Rafinesque, C.S. (1810). Caratteru di alcuni nuovi generi e nueve specie di animali (principalmente di pesci) e pinate della Sicilia, con varie osservazioni sopra i medisimi (pp. 105), Palermo, Italia.

Reinecke, T., Moths, H., Grant, A., \& Breitkreuz, H. (2005). Die Elasmobranchier des norddeutschen Chattiums, insbesondere des Sternberger Gesteins (Eochattium, Obere Oligozän). Palaeontos, $8,1-135$

Smith, H. M., \& Radcliffe, L. (1912). The squaloid sharks of the Philippine Archipelago. Proceedings of the United States National Museum, 41, 677-685.
Storms, R. (1894). Troisième note sur les poissons du terrain Rupélien. Bulletin de la Société belge de Géologie, de Paléontologie et d'Hydrologie, 8, 67-82.

Welton, B.J. (1979). Late Cretaceous and Cenozoic Squalomorphii of the NorthWest Pacific Ocean. pp. 53. Unpublished MSc thesis, University of California Berkeley, Berkeley.

Whitley, G. P. (1929). Additions to the Check-list of the Fishes of New South Wales. Australian Zoologist, 5(4), 353-357.

Winkler, T.C. (1874). Mémoires sur des dents de poissons du terrain bruxellien. Archives du Musée Teyler, 3(4), 295-256. 